\title{
Stabilising Urea Amine Nitrogen Increases Potato Tuber Yield by Increasing Chlorophyll Content, Reducing Shoot Growth Rate and Increasing Biomass Partitioning to Roots and Tubers
}

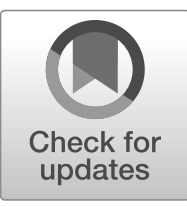

\section{Sally Wilkinson, et al. [full author details at the end of the article]}

Received: 14 March 2019 / Accepted: 9 August 2019 /

Published online: 16 December 2019

(C) The Author(s) 2019

\begin{abstract}
Much of the nitrogen in crop fertiliser is degraded before acquisition. Technologies that stabilise urea-nitrogen minimise this. Degradation also specifically reduces the amount of ureic amine that many fertilisers initially contain, which is important because this nitrogen form has unique beneficial effects on plants. To investigate mechanisms whereby urea stabilisation increases potato tuber yield, we compare effects of foliar applications of chemically stabilised and non-stabilised urea against industry-standard fertiliser, on the physiology, form and yield of greenhouse-grown Casablanca under identical nitrogen supply. Stabilised urea is tested on Rooster and Shelford yields in Irish and British field trials. Stabilised amine nitrogen (SAN) increases Casablanca leaf relative chlorophyll content and initially reduces shoot growth rate. When harvested shortly after tuber initiation, SAN-treated plants have increased root to shoot weight ratios and we find tight negative correlations between shoot growth rate and root weight: large roots and slow shoot extension occur predominantly in SAN-treated plants. SAN increases ratios between initiation-stage tuber weight and (a) shoot length and (b) shoot growth rate. At a second harvest at mid-bulking, SAN increases highgrade Casablanca tuber yielding. At this later stage, yield correlates positively with shoot weight. In the field, SAN increases Rooster canopy greenness and marketable yields of both Rooster and Shelford. Yield improvements specific to this $\mathrm{N}$ form when stabilised are suggested to occur through increased photosynthesis and early-stage increases in root to shoot weight ratio. This phenotype then supports increased bulking-stage shoot growth and shoot-sourced resource for tuber growth. Stabilising urea amine induces high-yielding phenotypes with improved internal nitrogen utilisation efficiencies.
\end{abstract}

Keywords Foliarurea fertiliser $\cdot$ Food production $\cdot$ Nitrogen form · Organic nitrogen $\cdot$ Rootshoot ratio 


\section{Introduction}

By 2050, the global human population is expected to rise to 10 billion, and yields of the world's fourth largest food crop_potato (Solanum tuberosum L.) - need to be increased. However, it is important for the environment that nitrogen fertiliser production and use does not increase in parallel. Present-day methods of supplying plants with nitrogen $(\mathrm{N})$, in the form of ammonium nitrate- or urea-based fertilisers, are inefficient: up to $70 \%$ of this $\mathrm{N}$ is degraded before plants can acquire it, forming harmful greenhouse gases and leaching polluting nitrate into water systems (Liu et al. 2013); and governments are legislating to control their use (Cantarella et al. 2018). Technologies that stabilise ureic nitrogen in fertiliser, such that it is less easily degraded, can reduce pollution whilst prolonging nitrogen availability to plants. This means that lower fertiliser application rates are viable for attaining the required increases in the production of many crops (Prasad et al. 2016). However, we propose that urea and ureic amine are nitrogen forms that have unique properties that improve plant form and function, such that their stabilisation also increases yield by mechanisms unrelated to prolonging the availability of nitrogen per se.

Urea is an organic amide with the chemical formula $\mathrm{CO}-\left(\mathrm{NH}_{2}\right)_{2}$. It has two amine $\left(\mathrm{NH}_{2}\right)$ groups joined by a carbonyl functional group. It is present in natural ecosystems as well as being a constituent of man-made nitrogenous fertiliser. In natural systems, it enters the soil and canopy from urine excreted by animals (Barthelemy et al. 2018); and/or bulky organic matter is broken down by a range of organisms, such as fungi and bacteria, to smaller organic molecules. Plants have evolved sophisticated mechanisms to take up urea from the environment (Neff et al. 2003; Schimel and Bennett 2004); however, bacterial organisms that break it down by secreting the enzyme urease are ubiquitous in soil and on leaf surfaces (Hoult and McGarity 1986; Witte et al. 2002; Dawar et al. 2011) such that urea is only transiently available. Ureases induce urea to hydrolyse within minutes, whether it is naturally present or added as fertiliser, converting it to gaseous ammonia and carbon dioxide $\left(\mathrm{NH}_{2} \mathrm{CONH}_{2}+\mathrm{H}_{2} \mathrm{O} \rightarrow 2 \mathrm{NH}_{3}+\right.$ $\mathrm{CO}_{2}$ ), which are then lost via volatilisation to the atmosphere, the extent of which varies with wind speed, temperature, soil $\mathrm{pH}$ and water content (Soares et al. 2012; Cantarella et al. 2018). Other soil bacteria induce nitrification of ammonium to leachable nitrate. Despite recognition that crop fertilisation with urea is wasteful and environmentally deleterious, it is currently the primary global fertiliser for crop production (Heffer and Prud'hommer 2014) because it is relatively cheap to manufacture and easily transported and contains $46 \% \mathrm{~N}$.

Since the advent of large-scale crop fertilisation and the recognition that it is innately inefficient, much effort has been directed towards the development of more sophisticated fertilisers, co-products and application mechanisms. For example, there are several benefits to providing nitrogen to crops via the foliage, usually as solutions which can be applied as a fine spray. These include reductions in leaching and the ability to provide nitrogen when root activity is impaired, e.g. in saline or dry conditions (Gooding and Davies 1992; del Amor et al. 2009). A second example concerns urea itself: methods of stabilising it, and slowing its hydrolysis to $\mathrm{NH}_{3}$ and $\mathrm{CO}_{2}$ by urease, have been developed (e.g. Bhogal et al. 2003; Chalk et al. 2015; Cantarella et al. 2018). Thus far, methods of stabilisation and their effects on yield have been met with mixed success. One such technology provides urease inhibitors as 
constituents of urea-based fertilisers to prolong the existence of the ureic nitrogen element (Trenkel 2010). The most widely used of these is $N$-(n-butyl) thiophosphoric triamide (NBPT) (e.g. Watson and Miller 1996). In some cases, nitrogen use efficiency (NUE, the amount of nitrogen taken up by the crop, as a percentage of that applied) has been promoted (Zvomuya et al. 2003; Arkoun et al. 2012); however, the urease inhibitors themselves pass into roots and/or leaves, preventing natural ureic assimilation within plant tissues, allowing internalised urea to build to toxic levels (Krogmeier et al. 1989). Furthermore, alterations of urea assimilation within root or leaf tissue mean that most of the urea provided fails to release the bound nitrogen that it contains; and the transcriptional profiles of genes involved in primary and secondary metabolism are altered, to the detriment of the plant (Zanin et al. 2016). Alternative methods of stabilisation involve the manufacture of urea granules with semi-permeable coatings, such as sulphur and polyurethane. These reduce some of the degradation to other $\mathrm{N}$ forms and pollutants by forming a physical barrier to slow urea solubilisation. Yields can be either maintained at lower $\mathrm{N}$ input, or, importantly, increased (Wang et al. 2015; Tiana et al. 2018), including in potato (Hutchinson et al. 2002; Hyatt et al. 2009); and ammonia and $\mathrm{CO}_{2}$ volatilisation and nitrate leaching can be reduced, thereby increasing NUE (Zvomuya et al. 2003; Soares et al. 2012).

Despite the fact that urea has long been used as a fertiliser, it is only relatively recently that scientific studies of its uptake, utilisation and effects in plants have begun to proliferate (e.g. Witte 2011). An earlier view was that organic nitrogen needed to be degraded to inorganic forms by microorganisms, before plants could acquire the $\mathrm{N}$ it contains (see Paungfoo-Lonhienne et al. 2008; Zanin et al. 2016). As such, more knowledge is available regarding the uptake and effects of inorganic ammonium and nitrate in plants. However, it is now recognised that urea is easily taken up from soil by roots, through specific cell membrane transport proteins and/or aquaporins. It is rapidly assimilated via hydrolysis in the root cytosol by non-bacterial plant-specific urease, releasing ammonium and carbon dioxide internally, or transported to leaves when roots are no longer the dominant sink. Urea-sourced ammonium produced internally is rapidly assimilated by a second cytosolic pathway (Witte 2011; Zanin et al. 2016), to provide proteinaceous substrate for plant growth, photosynthesis and functioning.

In unstressed plants, different $\mathrm{N}$ forms are assimilated to protein via different mechanisms, which have different costs in terms of resource use and which are located in different organs and cell types; and this has repercussions for plant functioning and anatomical form (Zerihun et al. 1998; Andrews et al. 2013). A large fraction of nitrate $\mathrm{N}$ taken up by roots from soil is, in many cases, delivered to leaves, where the components for its assimilation are predominantly located. Nitrate-fertilised plants thus preferentially use the assimilate for above-ground growth. However, the components for the assimilation of $\mathrm{N}$ provided as ammonium are found within roots when these are actively growing; thus, root growth is initially favoured over shoot growth. This biomass partitioning gives rise to plants with differing anatomical appearances, or phenotypes, which are particular to each $\mathrm{N}$ form. Organic $\mathrm{N}$ forms such as urea are also assimilated in roots as described above, and organically fertilised plants are also characterised by increased biomass partitioning to roots, forming phenotypes with increased root to shoot weight ratios under experimental conditions (Franklin et al. 2017). The enhanced root to shoot weight ratio of urea-fertilised plants, in comparison to nitrate-fertilised plants, allows amplification of their capacity to scavenge soil for the 
water and nutrients required for enhanced above-ground growth at more advanced growth stages (Zerihun et al. 1998; Cambui et al. 2011; Franklin et al. 2017). However, in the field, such effects can be negated by the transient availability of urea. On this basis, our objective is to demonstrate that supplying stabilised ureic amine to potato will eventually lead to increases in tuber yield in glasshouse experiments and in the field, by producing phenotypes which permit this: more root and tuber mass per unit of shoot mass. We have shown that potato yields are lifted by such technology in UK field trials (Marks et al. 2018).

The amount of resource consumed during assimilation also varies with nitrogen form. Assimilation of inorganic nitrate in leaves requires the operation of the nitrate reductase pathway, which consumes more of the plant's energy and carbon (C) from photosynthesis, than any other $\mathrm{N}$ assimilation mechanism (Sunil et al. 2013; Franklin et al. 2017). More protein, energy and $C$ will thus be available for photosynthesis and biomass growth under urea or ammonium nutrition. However, ammonium can be toxic to plants as it affects the $\mathrm{pH}$ balance. Resource-consuming processes are used by plants to mitigate this effect, such that ureic amine assimilation may be the most resource efficient, and provide the most protein.

Thus, stabilising urea amine has the potential to promote NUE, internal nitrogen utilisation efficiency, crop productivity per unit of applied nitrogen (partial factor productivity) and yielding per se, in multiple ways: (a) it can increase nitrogen longevity in the environment whilst reducing pollution; (b) cytosolic ureic nitrogen and its hydrolytic product, ammonium, induce the development of phenotypes which initially favour root growth over vegetative growth; and (c) less energy and carbon are used to assimilate urea amine nitrogen than nitrate and ammonium nitrogen, thus more is available for photosynthesis and biomass growth. We have shown that ureic amine stabilisation increases shoot biomass, leaf relative chlorophyll content and flower numbers in a range of horticultural species (Wilkinson et al. 2019).

That urea is preferentially assimilated in roots when applied to soil has been shown to be linked to increases in root to shoot weight ratio; however, foliarly applied urea is also at least partially assimilated in leaves (Witte et al. 2002). It is not known whether ureic amine will have the same desired effect on root to shoot (or tuber to shoot) ratio when applied foliarly, and here we investigate this possibility. The leaf cuticle is up to 10 times more permeable to urea than to inorganic nitrogen ions, and this may be an adaptation to the transient nature of urine urea availability in natural systems (Wojcik 2004). Urea entering plants from foliar applications is cycled through a range of tissues, and is allocated within $48 \mathrm{~h}$ to the strongest sinks (Klein and Weinbaum (1985), olive; Witte et al. (2002), potato).

Additionally, effects that ureic amine stabilisation may have on root to shoot ratio could be less easy to define in a tuber crop. Many of these, including potato, have relatively small, weak basal root systems. However, urea stabilisation should also benefit other developmental processes such as tuberisation and bulking more directly. Potato tubers are not formed from a root (Hannapel et al. 2017); they arise from specialised underground stems called stolons, the tips of which swell to form the tuber. The developing tubers are important sinks for nitrogen, and we propose that foliar ureic amine-sourced $\mathrm{N}$ can have positive effects at this stage by increasing shoot biomass and photosynthesis. When cells begin to divide and expand, tubers start to enlarge and form starch, or 'bulk'. Bulking tubers are sinks that import phloem-mobile substances from 
leaves, such as sucrose for starch formation (Hannapel et al. 2017). We propose that bulking-stage applications of foliar urea $\mathrm{N}$ could increase biomass allocation to developing tubers via increased sucrose production and transport.

We describe here effects of a chemical method of stabilising urea-sourced amine $\mathrm{N}$ in foliar applications, developed by Levity Crop Science Ltd. (Preston, UK), on changes in physiology, form and yield of potato. We compare effects of this stabilised amine nitrogen (SAN) with those of non-stabilised urea and a commercially available industry-standard $\mathrm{N}-\mathrm{P}-\mathrm{K}$, where all formulations contain identical amounts of $\mathrm{N}$ by weight. The variety Casablanca is used in greenhouse experiments. SAN is also tested on the physiology and tuber yields of Rooster and Shelford in the field in Ireland and England. Casablanca is generally a first early crop, and main crop Rooster tubers are large and are used for chipping, mashing and roasting. Shelford is an early main crop, and tubers are often used for crisping. We investigate whether the proposed yield increase induced by stabilisation is merely a result of reducing degradation and prolonging nitrogen availability, or whether alterations in biomass partitioning and chlorophyll concentration specifically induced by ureic amine $\mathrm{N}$ also make a contribution.

\section{Materials and Methods}

Solanum tuberosum L. cv. Casablanca (85G040-080 × Picasso; Suttons Seeds, Woodview Road, Paignton, Devon, UK, TQ4 7NG), cv. Rooster (OP $253264 \times$ Pentland Ivory) and cv. Shelford (FL1625 × Hermes) were used in this study. Casablanca was used in the greenhouse trials. Rooster and Shelford crops were tested in field trials on commercial farms.

\section{Glasshouse Experiments}

Chitted Casablanca tubers of approximately $7-8 \mathrm{~cm}$ in length were planted in May 2017, in 13.5- $\mathrm{L}^{-1}$ buckets perforated at the base, containing J. Arthur Bowers John Innes No. 2 compost (Westland Horticulture Ltd., Co., Tyrone, UK), at a rate of one per container, placed $4-6 \mathrm{~cm}$ below the soil surface. The $\mathrm{pH}$ of this compost is 5.56.0, and it provides appropriate macro- and micronutrients to plants in all treatments for the first 3 to 4 weeks, including boron and calcium. Plants were allowed to grow to an average stem height of 10-12 $\mathrm{cm}$ prior to experimental treatments (June), in a heated and ventilated glasshouse under natural light (PPFD 200-1000 $\mu \mathrm{mol} \mathrm{m} \mathrm{m}^{2} \mathrm{~s}^{-1}$ ), in Preston, northern England, UK. Nighttime temperature was $12-16{ }^{\circ} \mathrm{C}$ and daytime temperature was $16-32{ }^{\circ} \mathrm{C}$. Plants were watered by hand to soil capacity as required, taking care not to over-water. Each of the three treatments (see below) comprised of 12 replicate potato plants (seven for the first harvest, five for the final harvest) which were randomised within an area of $8.0 \times 1.5 \mathrm{~m}^{2}$. Two harvests were carried out: one in August and one in September 2017.

Plants were treated with foliar sprays containing nitrogen $(\mathrm{N})$ fertiliser in three formulations: an industry-standard N-P-K control (IS), stabilised amine nitrogen (SAN) in a formulation called 'Lono' (supplied by Levity Crop Science Ltd., Preston, $\mathrm{UK}$ ) and standard unstabilised urea (SU). SAN was supplied at $0.1 \mathrm{mmol} \mathrm{m}^{-3}$, 
equivalent to a rate of $5.0 \mathrm{~L} \mathrm{ha}^{-1}$ in $200 \mathrm{~L}$ water. IS was supplied at $1.4 \mathrm{mmol} \mathrm{m}^{-3}$. SU was supplied at $0.03 \mathrm{mmol} \mathrm{m}^{-3}$. SAN contains $15 \% \mathrm{~N}$ (by weight), and the IS and SU treatments were designed to provide the same amount of $\mathrm{N}$ to the plants (given that IS contains $24 \% \mathrm{~N}$ and SU contains $46 \% \mathrm{~N}$ by weight). Commercial IS contains a mixture of ureic and ammonium nitrate N. All three treatments were supplemented with industry-standard N-P-K (IS) at one-quarter recommended strength every 10-12 days, approximately mid-way between main treatment dates, ensuring access to sufficient micronutrients and $\mathrm{P}-\mathrm{K}$. Plants were treated with $\mathrm{N}$ fertiliser over the course of the following weeks at the times detailed in Table 1, at a rate of $20 \mathrm{~cm}^{3}$ per square metre of planting area.

Over the course of the experiments ( 24 days or 46 days), plants were treated with the appropriate $\mathrm{N}$ compound every 10-14 days (as specified in Table 1) and leaf relative chlorophyll content and shoot length, number and extension rates were measured on several occasions (Table 1). One group of plants (seven replicates) was harvested shortly after tuber initiation, and divided into tissue types (shoots, seed potato, roots and new tubers (1-2-cm stage)) and weighed immediately. A second group of plants (five replicates) was harvested 3 weeks later at mid-bulking. Shoots and new tubers (4$6 \mathrm{~cm}$ ) were weighed and counted, and a version of 'marketable' tuber weight was designated as 5-25 $\mathrm{g} \mathrm{FW}^{-1}$.

Relative chlorophyll content was measured in leaves as an index, with a FieldScout CM 1000 Chlorophyll Meter (Spectrum Technologies Inc., IL, USA). 'Point-andshoot' technology instantly measures the reflectance of ambient and reflected 700-nm and 840-nm light in a conical viewing area on the adaxial leaf surface $30-180 \mathrm{~cm}$ from the light receptor. Laser guides outline the edges of the sampling area, allowing replication of the position of this between plants (we chose a 0.5 -cm-diameter area mid-way between the midrib and the leaf edge of the most recently matured leaves). The light receptor comprises four photodiodes: two for ambient light and two for reflected light from the leaf. Measurement units are calculated as an index of relative chlorophyll content: 0-999 $\pm 5 \%$.

Table 1 Time course detailing foliar nitrogen $(\mathrm{N})$ application occasions, and measurement and sampling activity, during experiments on greenhouse-grown Solanum tuberosum L. cv. Casablanca; beginning in May 2017 (early summer; Preston, Lancashire, England, UK)

\begin{tabular}{lll}
\hline Days from start & Activity & Figure no. \\
\hline 0 & N treatment 1 & \\
4 & Chlorophyll analysis & Fig. 1a \\
7 & Shoot lengths measured & Fig. 3 \\
11 & Shoot lengths measured & Fig. 3 \\
14 & N treatment 2 & \\
16 & Leaf count & \\
24 & First harvest & Figs. 4, 5, 6 \\
33 & N treatment 3 & \\
39 & Chlorophyll analysis & Fig. 1b \\
46 & Second harvest & Fig. 7 \\
\hline
\end{tabular}


The length of each shoot per plant was hand-measured with a ruler from the soil surface, and was also combined to give an overall length comprising all shoots per plant.

Means and standard errors of each measurement type per treatment are displayed as bar charts, and correlations between data sets are depicted on scatter graphs. The significance of the differences between treatments in bar chart form was calculated using a one-tailed $t$ test for two independent means, and where treatments are significantly different from each other $(p<0.1)$, this is denoted by ' $a$ ', ' $b$ ' or ' $c$ ', above the appropriate column on the graphic representations of the data. Best-fit trend lines on scatter graphs were calculated (linear or exponential) on Microsoft Excel, and $r^{2}$ values are provided. The significance of the $r$ value - the strength of the relationship — was calculated using the Pearson product-moment correlation and is represented as one asterisk $(p<0.1)$, two asterisks $(p<0.05)$ or three asterisks $(p<0.01)$.

\section{Summer-Autumn 2016 Field Trials}

\section{Hampshire, England, UK: Shelford}

Conditions on farm and dates of crop treatments, from sowing to harvest, are described in Table 2. Five replicate plots for each of the three experimental treatments were laid out in a randomised block design: (1) soil-applied commercial urea controls, (2) foliarstabilised amine nitrogen (SAN) applied three times, (3) foliar SAN applied four times. Foliar SAN applications were carried out at a rate of $5.0 \mathrm{~L} \mathrm{ha}^{-1}$ in $200 \mathrm{~L}$ water $\left(0.1 \mathrm{mmol} \mathrm{m}^{-3}\right)$ : the first application occurring at tuber initiation and the last at late bulking. Where treatments were applied only three times, either the tuber initiation treatment was withheld or the late bulking treatment was withheld.

Yield data is presented as follows: tuber count per plot, tuber yield per plot $(\mathrm{kg})$, tuber count per hectare, yield per hectare (metric tonnes: $\mathrm{t} \mathrm{ha}^{-1}$ ). Tubers were graded

Table 2 Field conditions on-farm in Hampshire, England, UK; and activity time course to harvest of crop (Solanum tuberosum L. cv. Shelford)

\begin{tabular}{|c|c|}
\hline \multicolumn{2}{|c|}{$\begin{array}{l}\text { Shelford } \\
\text { Previous crop: Wheat } \\
\text { Soil type: Sandy (no ridging required) } \\
\text { Bed preparation: Ploughed, de-stoned } \\
\text { Fertiliser rate: } 180 \mathrm{~kg} \mathrm{~N} \mathrm{~h}^{-1} \text { as urea } \\
\text { Irrigation: Yes }\end{array}$} \\
\hline Date & Activity \\
\hline May 03, 2016 & $\begin{array}{l}\text { - Fertiliser broadcast } \\
\text { - Crop sown }\end{array}$ \\
\hline June 24, 2016 & SAN treatment 1 \\
\hline July 08, 2016 & SAN treatment 2 \\
\hline July 22, 2016 & SAN treatment 3 \\
\hline August 05, 2016 & SAN treatment 4 \\
\hline August 26, 2016 & Harvest \\
\hline
\end{tabular}


into categories by tuber size $(<40 \mathrm{~mm}, 40-60 \mathrm{~mm}, 60-80 \mathrm{~mm},>80 \mathrm{~mm}$ (split tuber number was assessed visually)), and marketable yield was $40-80 \mathrm{~mm}$.

Means and standard errors of yield data for the three treatments (control, SAN 3 applications, SAN 4 applications) are displayed as bar charts. The significance of the differences between treatments in bar chart form was calculated using a one-tailed $t$ test for two independent means, and where treatments are significantly different from each other $(p<0.1)$, this is denoted by ' $a$ ', 'b' or 'c', above the appropriate column on the graphic representations of the data.

\section{County Meath, Ireland: Rooster}

Conditions on farm and dates of crop treatments, from sowing to harvest, are described in Table 3. Three different nitrogen treatments were applied to four replicated plots each, set out in a randomised block design: (1) soil-applied commercial $\mathrm{N}$ fertiliser controls $\left(55 \mathrm{~kg} \mathrm{ha}^{-1}\right)$, (2) SAN applied foliarly three times, (3) SAN applied foliarly four times. Foliar SAN was applied at a rate of $5.0 \mathrm{~L} \mathrm{ha}^{-1}$ in $200 \mathrm{~L}$ water $\left(0.1 \mathrm{mmol} \mathrm{m}^{-3}\right)$, with the first application occurring at tuber initiation and the last at late bulking. Where treatments were applied only three times, the tuber initiation treatment was withheld.

Green leaf area (percentage of all leaves) was assessed visually on 13 September, in 3 plants per plot. Yield data is presented $\left(\mathrm{t} \mathrm{ha} \mathrm{h}^{-1}\right)$ for small tubers $(<45 \mathrm{~mm})$, marketable tubers $(45-65 \mathrm{~mm})$, oversized tubers $(>65 \mathrm{~mm})$ and gross weight (minus large tubers).

Means, standard errors and significance levels of green leaf area and yield data were calculated as described for the Shelford trial above, and presented as bar charts.

Table 3 Field conditions on-farm in County Meath, Ireland; and activity time course to harvest of crop (Solanum tuberosum L. cv. Rooster)

\begin{tabular}{|c|c|}
\hline \multicolumn{2}{|c|}{$\begin{array}{l}\text { Rooster } \\
\text { Previous crop: Winter barley } \\
\text { Soil type: Clay/loam } \\
\text { Bed preparation: Fertiliser incorporated } \\
\text { Fertiliser rate: } 55 \mathrm{~kg} \mathrm{~N} \mathrm{~h}^{-1} \text { as urea } \\
\text { Irrigation: Yes }\end{array}$} \\
\hline Date & Activity \\
\hline May 20, 2016 & $\begin{array}{l}\text { - Crop sown } \\
\text { - Beds ridged and de-stoned }\end{array}$ \\
\hline June 27, 2016 & SAN treatment 1 \\
\hline July 11, 2016 & SAN treatment 2 \\
\hline July 25,2016 & SAN treatment 3 \\
\hline August 08, 2016 & SAN treatment 4 \\
\hline September 13, 2016 & Green leaf area assessed \\
\hline November 01, 2016 & Harvest \\
\hline
\end{tabular}




\section{Results}

\section{Leaf Relative Chlorophyll Content and Green Canopy Index}

Figure 1 demonstrates that, in greenhouse-grown Casablanca, $\mathrm{N}$ fertiliser supplied as SAN increased relative chlorophyll content of leaves in comparison to industrystandard treatment (IS controls), and in comparison to standard (unstabilised) urea treatments (SU): 4 days after the first treatment (Fig. 1a) and 4 days after the third treatment (Fig. 1b). The SAN-induced increase (11\%) was significantly higher than IS and SU treatments in Fig. 1b, and significantly higher than IS (8\%) in Fig. 1a. SU had no effect on chlorophyll content compared with IS.

Figure 2 demonstrates that, 6 weeks prior to harvest, the percentage of the canopy of field-grown Rooster plants that was green (high in chlorophyll) was significantly increased by SAN compared with control fertiliser treatment, by $9 \%$, both when SAN was applied 3 times and when it was applied 4 times.

\section{Shoot Physiology}

Nitrogen form affects the growth rate of Casablanca shoots over a 4-day period just prior to tuber initiation (Fig. 3a): SAN treatments significantly reduced shoot extension rate by $40 \%$ in comparison with IS and SU, although all treatments contained the same amount of $\mathrm{N}$ by weight. Figure $3 \mathrm{~b}$ shows that SU-treated plants had longer shoots than IS- and SAN-treated plants at tuber initiation. Leaf number per shoot was unaffected by treatment.

\section{Root and Shoot Tissue Weights at Tuberisation-Stage Harvest: Links with Shoot Physiology}

When Casablanca was harvested shortly after tuberisation, and tissues freshly weighed, SAN plants had the highest root weight, although this was not significant at this early
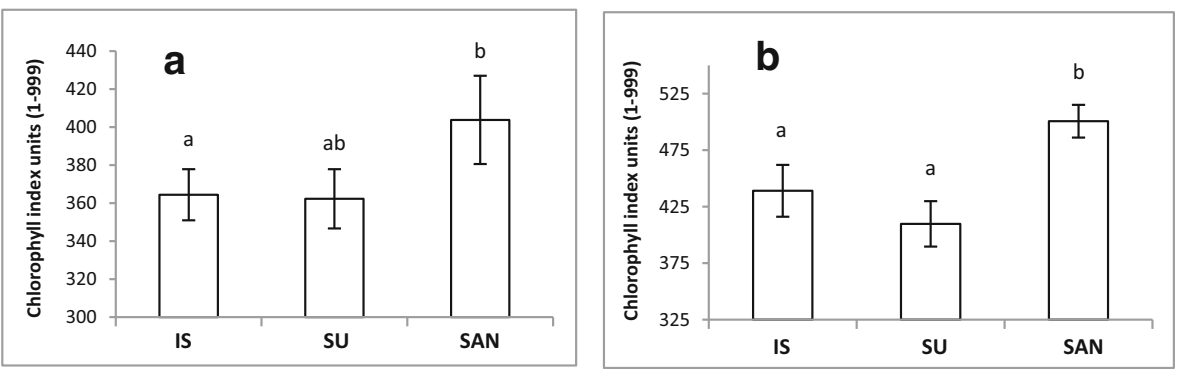

Fig. 1 a, b Effect of fertiliser nitrogen (N) form on leaf chlorophyll content of greenhouse-grown Solanum tuberosum L. cv. Casablanca plants: (a) 4 days after first $\mathrm{N}$ application and (b) 6 days after third $\mathrm{N}$ application. Effects of foliar applications of stabilised amine nitrogen (SAN, $0.1 \mathrm{mmol} \mathrm{m}^{-3}$ ), industry-standard NPK (IS, $1.4 \mathrm{mmol} \mathrm{m}^{-3}$ ) and standard non-stabilised urea (SU, $0.03 \mathrm{mmol} \mathrm{m}^{-3}$ ) are compared. Means \pm standard errors are shown $(n=7)$, and significant differences between treatments are denoted by differing letters above each column $(p<0.1)$ 


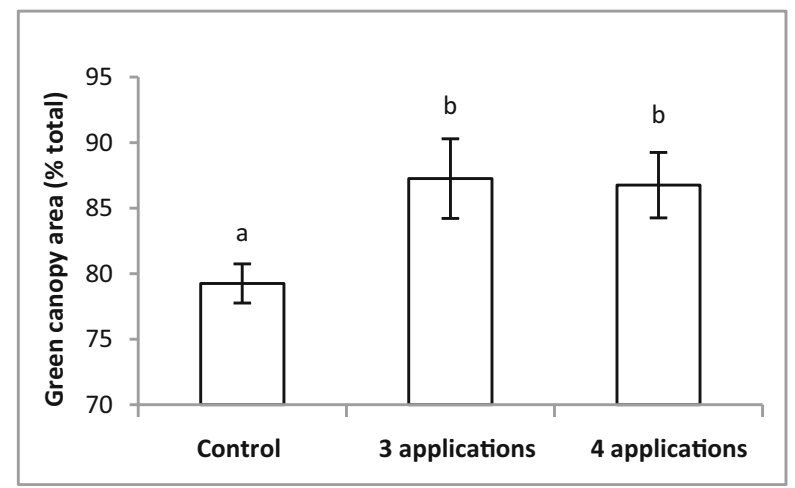

Fig. 2 Effect of fertiliser $\mathrm{N}$ form and application rate on green canopy area (\% total) of field-grown Solanum tuberosum L. cv. Rooster plants 6 weeks prior to harvest. The field trial was carried out in Ireland in 2016, and foliar SAN applications $\left(5.0 \mathrm{~L} \mathrm{ha}^{-1}\right.$ in $200 \mathrm{~L}$ water, or $0.1 \mathrm{mmol} \mathrm{m}^{-3}$ ) had either been carried out either 3 or 4 times prior to measurement, or not at all (controls). Three plants from each of 4 replicate plots were assessed visually, and means \pm standard errors are shown $(n=12)$, with significant differences between treatments denoted by differing letters above each column $(p<0.1)$

stage, whilst there were no treatment effects on shoot weight (data not shown). However, SU plants had the lowest root to shoot weight ratio, i.e. the least amount of root per unit of shoot (Fig. 4a). Control IS plants had higher root to shoot ratios than SU, and SAN plants had the highest root to shoot ratios of all. Figure $4 \mathrm{~b}$ shows that SAN plants also had the highest root to seed potato weight ratio, this being significantly higher than for SU-treated plants: more root weight per unit of seed potato weight. However, there was no difference in shoot to seed potato weight ratios between treatments (Fig. 4c).

When shoot number (Fig. 5a), which is established at chitting, was plotted against root weight, there was a significant negative relationship, with plants with the most shoots having the lowest root weight at this growth stage. However, this was only apparent in urea-treated plants, whilst shoot numbers in IS and SAN plants were not correlated with root weights at all. Similarly, root weight to shoot length ratios were lowest in SU-treated plants (Fig. 5b), i.e. plants with the longest shoots had the lowest root weights. Shorter shoots
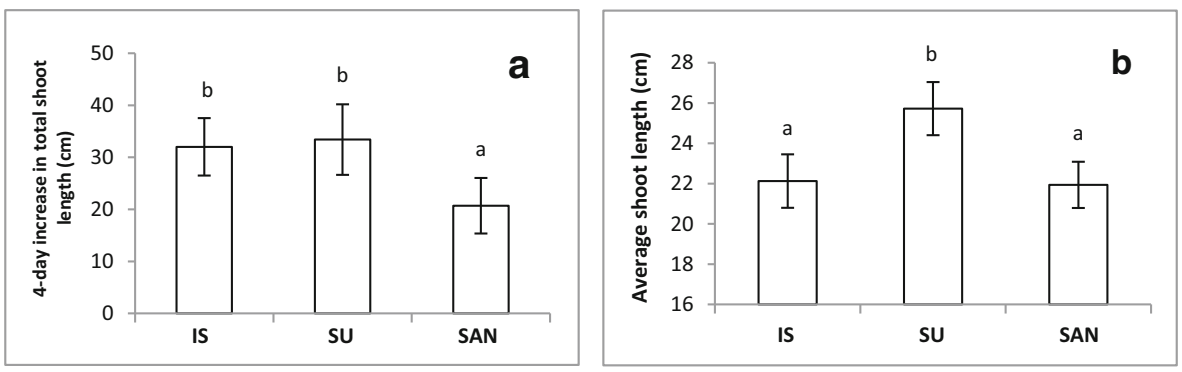

Fig. 3 a, b Effect of fertiliser N form on greenhouse-grown Solanum tuberosum L. cv. Casablanca: (a) shoot growth rate, and (b) average shoot length per plant; (a) between 7 and 11 days, and (b) 11 days after the first foliar application of IS (industry-standard fertiliser), SU (standard urea) or SAN (stabilised amine nitrogen) at 1.4, 0.03 and $0.1 \mathrm{mmol} \mathrm{m}^{-3}$, respectively. Means \pm standard errors are shown $(n=7)$, and significant differences between treatments are denoted by differing letters above each column $(p<0.1)$ 

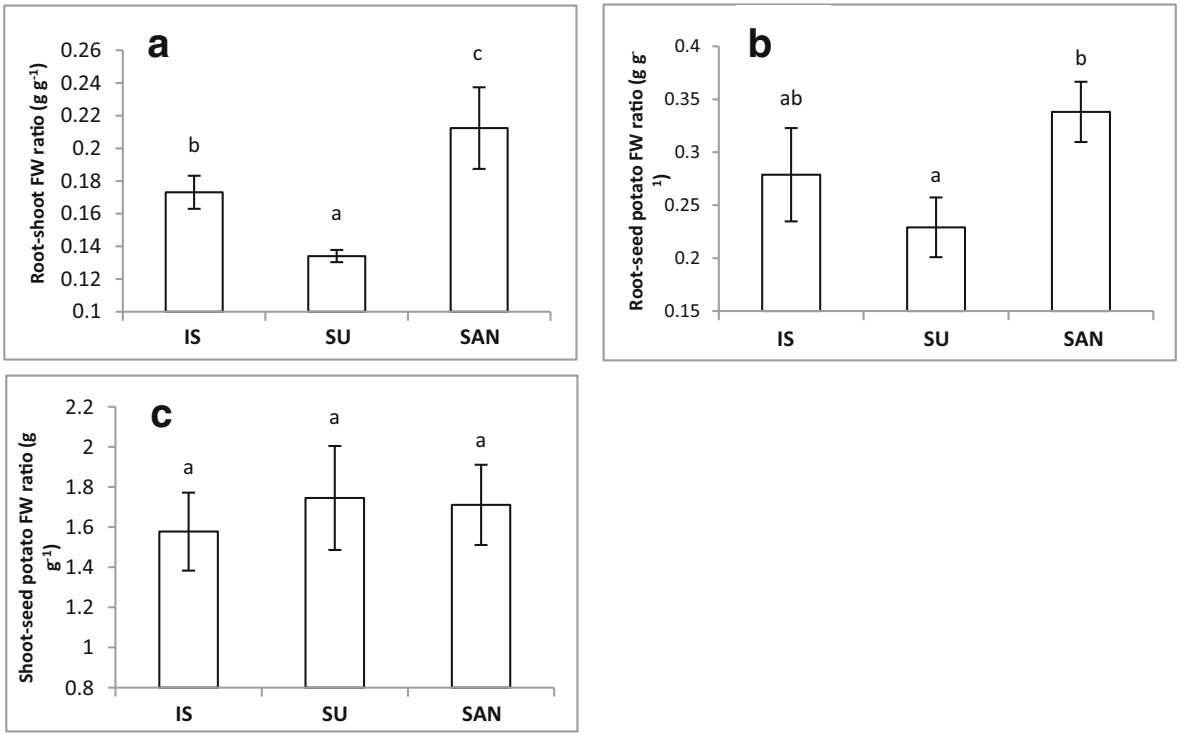

Fig. 4 a-c Effect of fertiliser N form on greenhouse-grown Solanum tuberosum L. cv. Casablanca tissue fresh weight (FW) ratios at first harvest: (a) root-shoot, (b) root-seed potato, (c) shoot-seed potato. First harvest, shortly after tuber initiation, occurred 10 days after a second foliar fertiliser application of IS (industry standard), SU (standard urea) or SAN (stabilised amine nitrogen) at 1.4, 0.03 and $0.1 \mathrm{mmol} \mathrm{m}^{-3}$, respectively. Ratios between tissue fresh weights were calculated, means \pm standard errors are shown $(n=$ 7), and significant differences between treatments are denoted by differing letters above each column $(p<0.1)$

were associated with the highest root weight, although there was no significant difference between control (IS) and SAN-treated plants in this regard (Fig. 5b). When total shoot length per plant was plotted against root to shoot weight ratio, there was a strong negative correlation (Fig. 5c), with SAN at the top left with short stems correlating with a high root to shoot ratio, and SU on the bottom right with long stems correlating with the lowest root to shoot ratio. Seed potato weight was also related to shoot length between treatments, with the highest shoot length to seed potato weight ratios being found in the SU treatments (not shown). Shoot growth rate was tightly and negatively correlated with root weight: when shoots grew faster, roots weighed less (Fig. 5d); and the slowest-growing shoots with the highest root weight were predominantly found in the SAN-treated plants. Whilst $\mathrm{N}$ form exerts an influence over relationships between shoot physiology and root weight in terms of shoot number, shoot length and shoot growth rate, a positive correlation between seed potato weight and the weight of all newly developed tissue cannot be overcome by any $\mathrm{N}$ form tested here (Fig. 5e). When root weight was plotted against shoot weight (Fig. 5f), there was a significant positive relationship within SAN-treated plants, as well as within the unstabilised urea treatment, such that both correlations increased in parallel. However, the relationship within the SAN-treated plants was shifted towards higher root weights, such 
that root weight at a certain shoot weight was always higher than in SU-treated plants.

\section{Tuber Harvest Characteristics}

\section{Tuber Initiation-Stage Harvest: Links with Plant Physiology}

Whilst there was no effect of treatment on potato tuber weight per se at this early stage (not shown), links between harvest weight and number, and plant physiology were clear (Fig. 6). Tuber yield expressed as weight per plant on a shoot growth rate basis was greatest in SAN-treated plants (Fig. 6a, b), such that slowest growth was associated with highest yield. Potato yield as weight was positively correlated with root weight, and this was significant within the IS treatment (Fig. 6c); however, SU plants had a significantly greater tuber weight per unit root weight than control IS plants (Fig. 6d) roots had to sustain a relatively higher tuber weight. There was also a significant positive correlation between shoot weight and tuber weight (Fig. 6e) within IS and SAN treatments (but not in SU), and SAN plants had more tuber weight per unit shoot weight, although this was not significant (Fig. 6f). There was no correlation between shoot number and tuber yield at this early stage.

\section{Mid-Bulking-Stage Harvest: Links with Plant Physiology}

Casablanca tuber harvest weights, designated 'marketable' (given that all tubers are sub-optimum weights due to the early harvest), were increased by SU and SAN compared with IS controls, but this yield increase was only significant with respect to SAN (Fig. 7a). On the other hand, Fig. $7 \mathrm{~b}$ shows that the number of underweight tubers per plant was reduced by SU and SAN, but that this reduction was only significant between IS and SAN. When 'marketable' tuber weight was expressed as a percentage of tuber gross harvest weight, the percentage of marketable tubers was greatest in SAN-treated plants, this being significant in comparison with SU, but not IS (Fig. 7c). When this was expressed as a percentage of total new plant biomass (root, shoot and tuber), the percentage of marketable tuber weight was also greatest for SAN-treated plants, being significantly higher than control IS-treated plants (data not shown). Figures $7 \mathrm{~d}-\mathrm{h}$ demonstrate links between tuber harvest and plant physiology (although roots were not weighed at this stage). The number of tubers expressed on a shoot number basis was significantly higher than control IS plants only in SAN-treated plants (Fig. 7d) - more tubers per shoot. Whilst SAN-treated plants exhibited a significant positive relationship between shoot fresh weight and marketable tuber number (Fig. 7e) and yield weight (Fig. 7f), within non-stabilised $\mathrm{N}$ treatments, this relationship $(r)$ is insignificant. A tight correlation also exists between leaf chlorophyll content and tuber yield (Fig. 7g). Higher chlorophyll content was associated with higher yield. At the lower end of the scale is the control IS treatment, with SU being intermediate and SAN having both a higher chlorophyll content and a higher yield. Interestingly, the difference between chlorophyll content at the start and the end of the experiment was also positively correlated with tuber yield (Fig. 7h). 

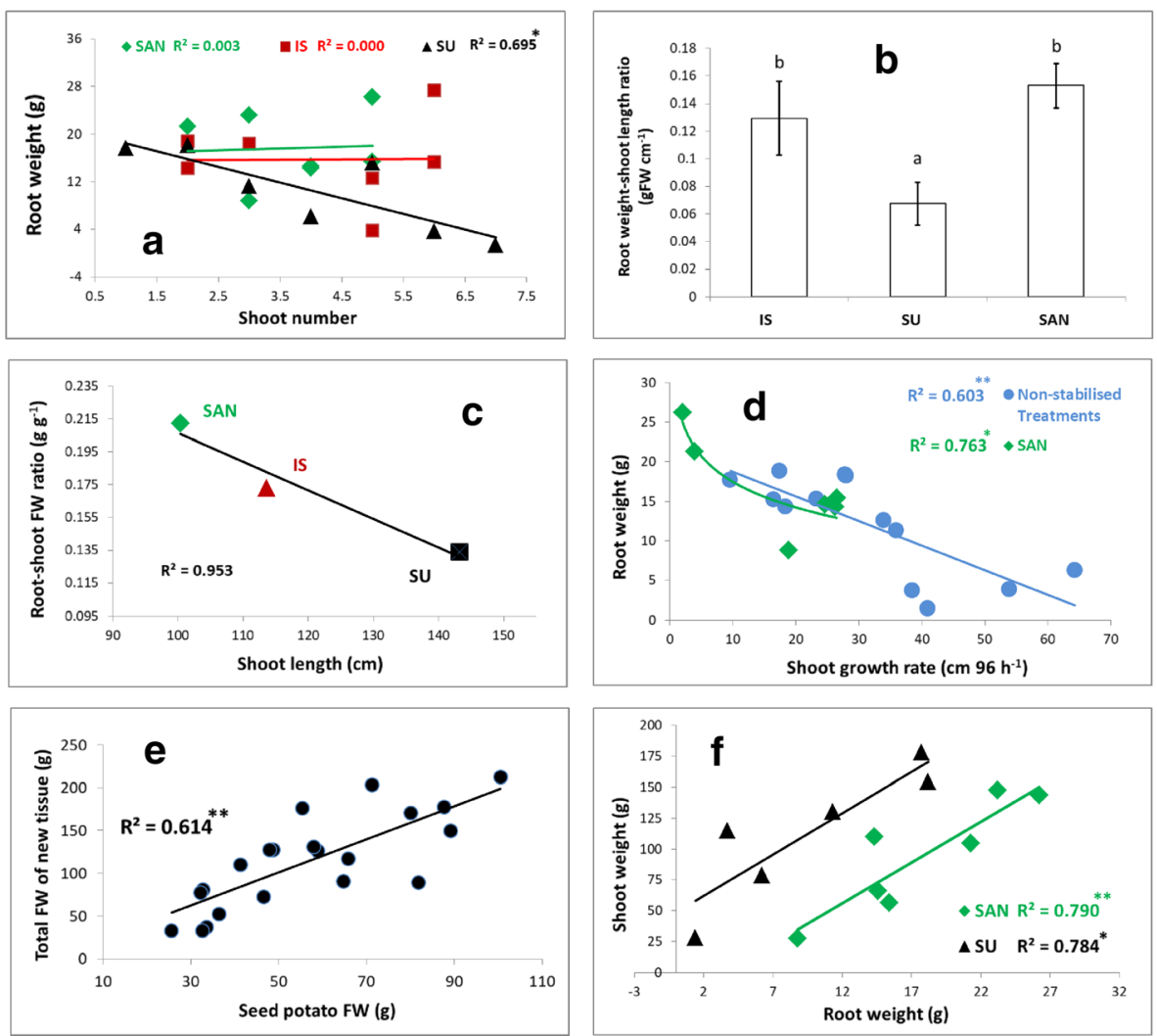

Fig. 5 a-f Effect of fertiliser $\mathrm{N}$ form on correlations and ratios between shoot characteristics and tissue weights in greenhouse-grown Solanum tuberosum L. cv. Casablanca at first harvest shortly after tuber initiation, 10 days after a second foliar fertiliser application of IS (industry standard), SU (standard urea) or SAN (stabilised amine nitrogen) at 1.4, 0.03 and $0.1 \mathrm{mmol} \mathrm{m}^{-3}$ respectively. SAN, green diamonds; IS, red squares; SU, black triangles; combined non-stabilised treatments, blue circles. Significant levels of Pearson product-moment $r^{2}$ correlations are represented as one asterisk $(p<0.1)$, or two asterisks $(p<0.05)$, and ratios between shoot characteristics and tissue fresh weights $(\mathrm{FW})$ are shown as means \pm standard errors $(n=7)$, with significant differences between treatments denoted by differing letters above each column $(p<0.1)$. Correlations are shown between the following: (a) shoot number and root FW, (b) root FW and shoot length, (c) shoot length and root-shoot FW ratio, (d) shoot growth rate and root FW, (e) seed potato FW and total new fresh tissue weight (all treatments combined, black circles), (f) shoot FW and root FW

\section{Field Trial Tuber Yields}

Figure 8 shows that foliar fertilisation with SAN in an English commercial farm setting gave rise to significantly higher marketable yields than control untreated plants in Shelford, both on a tuber number basis (Fig. 8a) and on a fresh weight basis (Fig. 8b). The yield increase was larger when the crop had received four applications (16\%) than when it had received three only (9\%). On an Irish commercial farm, yields of Rooster 

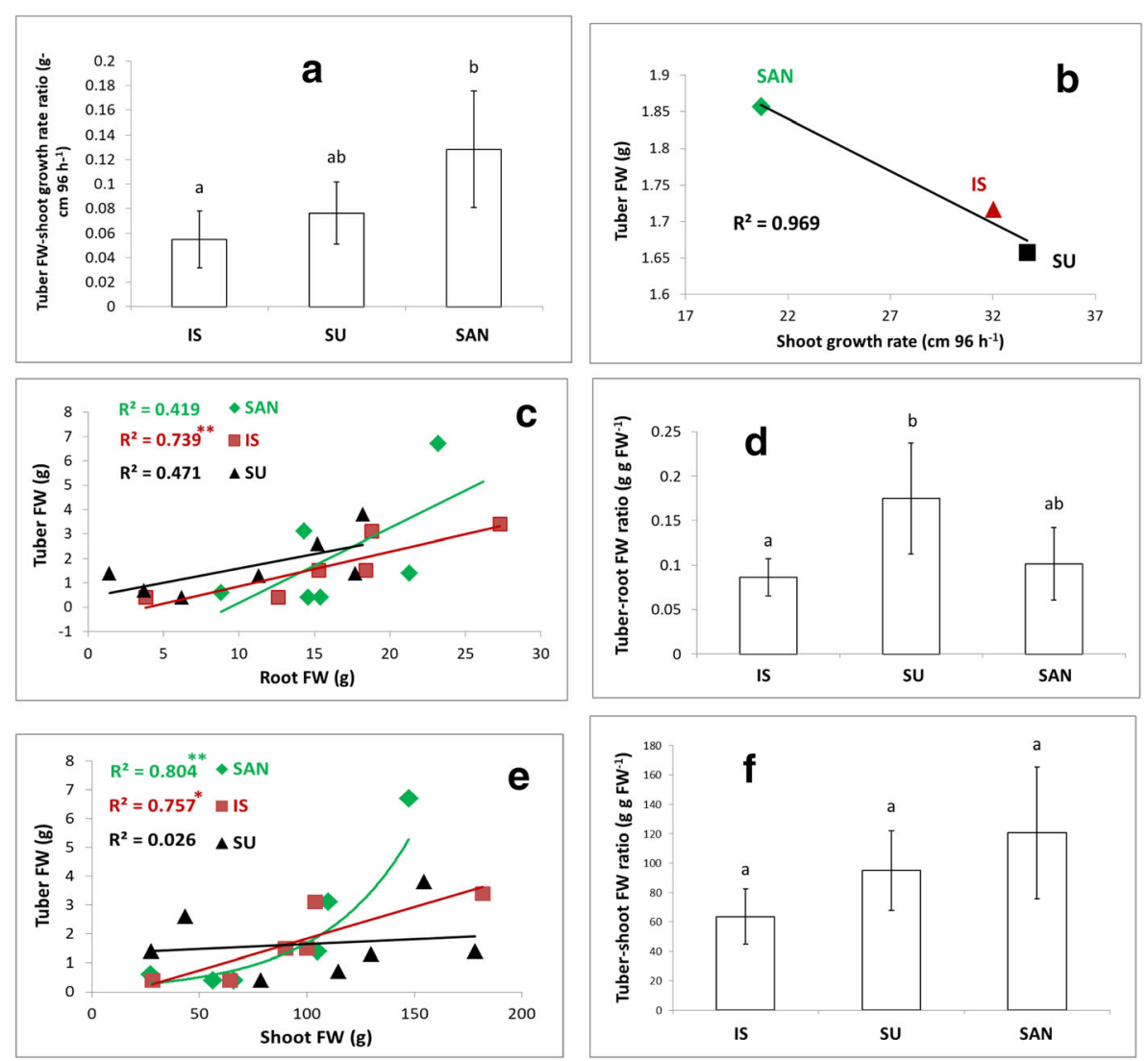

Fig. 6 a-f Effect of fertiliser $\mathrm{N}$ form on correlations and ratios between shoot characteristics and tuber fresh weights (FW) of greenhouse-grown Solanum tuberosum L. cv Casablanca at first harvest shortly after tuber initiation, 10 days after a second foliar fertiliser application of IS (industry standard), SU (standard urea) or SAN (stabilised amine nitrogen) at $1.4,0.03$ and $0.1 \mathrm{mmol} \mathrm{m}^{-3}$, respectively. SAN, green diamonds; IS, red squares; SU, black triangles; combined non-stabilised treatments, blue circles. Significant levels of Pearson product-moment $r^{2}$ correlations are represented as one asterisk $(p<0.1)$ or two asterisks $(p<0.05)$, and ratios between shoot characteristics and fresh weights are shown as means \pm standard errors $(n=7)$, with significant differences between treatments denoted by differing letters above each column $(p<0.1)$. Correlations and/or ratios are shown between the following: (a, b) tuber FW and shoot growth rate, (c-d) tuber FW and root FW, (e-f) tuber FW and shoot FW

were also greater when crops had been treated with SAN, although this was not quite significant (Fig. 8c). Giving four treatments did not increase yield above that of plants given only three treatments.

\section{Discussion}

We have previously shown that chemically stabilised urea increased potato yield in UK field trials (Marks et al. 2018, cv. Sassy) when applied foliarly. Here, we have characterised a range of physiological effects that could contribute to the similar increase in yields of Rooster and Shelford presented in Fig. 8: (a) increased relative 

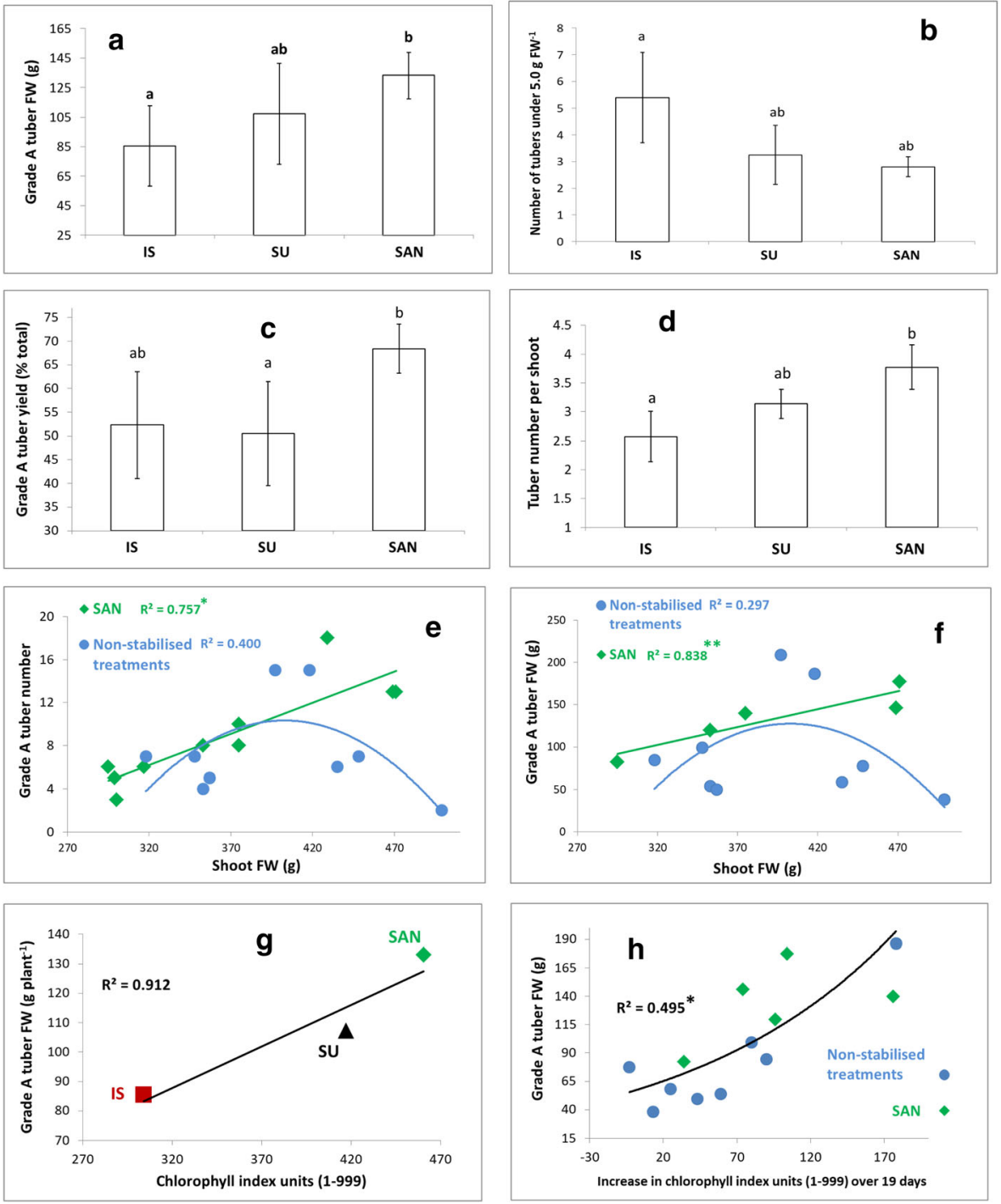

Fig. $7 \mathrm{a}-\mathrm{h}$ Effect of fertiliser $\mathrm{N}$ form on correlations and ratios between shoot characteristics and tuber fresh weights of greenhouse-grown Solanum tuberosum L. cv. Casablanca at second harvest at mid-bulking, 2 weeks after a third foliar application of IS (industry standard), SU (standard urea) or SAN (stabilised amine nitrogen) at $1.4,0.03$ and $0.1 \mathrm{mmol} \mathrm{m}^{-3}$ respectively. SAN, green diamonds; IS, red squares; SU, black triangles; combined non-stabilised treatments, blue circles. Significant levels of Pearson product-moment $r^{2}$ correlations are represented as one asterisk $(p<0.1)$, or two asterisks $(p<0.05)$, and ratios between shoot characteristics and tissue fresh weights (FW) are shown as means \pm standard errors $(n=7)$, with significant differences between treatments denoted by differing letters above each column $(p<0.1)$ : (a-c) tuber harvest FW, number and 'grade A' FW as a \% total harvest ('grade A' tubers designated as 5.0-25 g); (d) tuber FW and shoot number, (e-f) links with shoot FW, $(\mathrm{g}-\mathrm{h})$ links with leaf chlorophyll content $\left(\mathrm{h}\right.$ : correlation and $\mathrm{r}^{2}$ values comprise all $3 \mathrm{~N}$ treatments) 

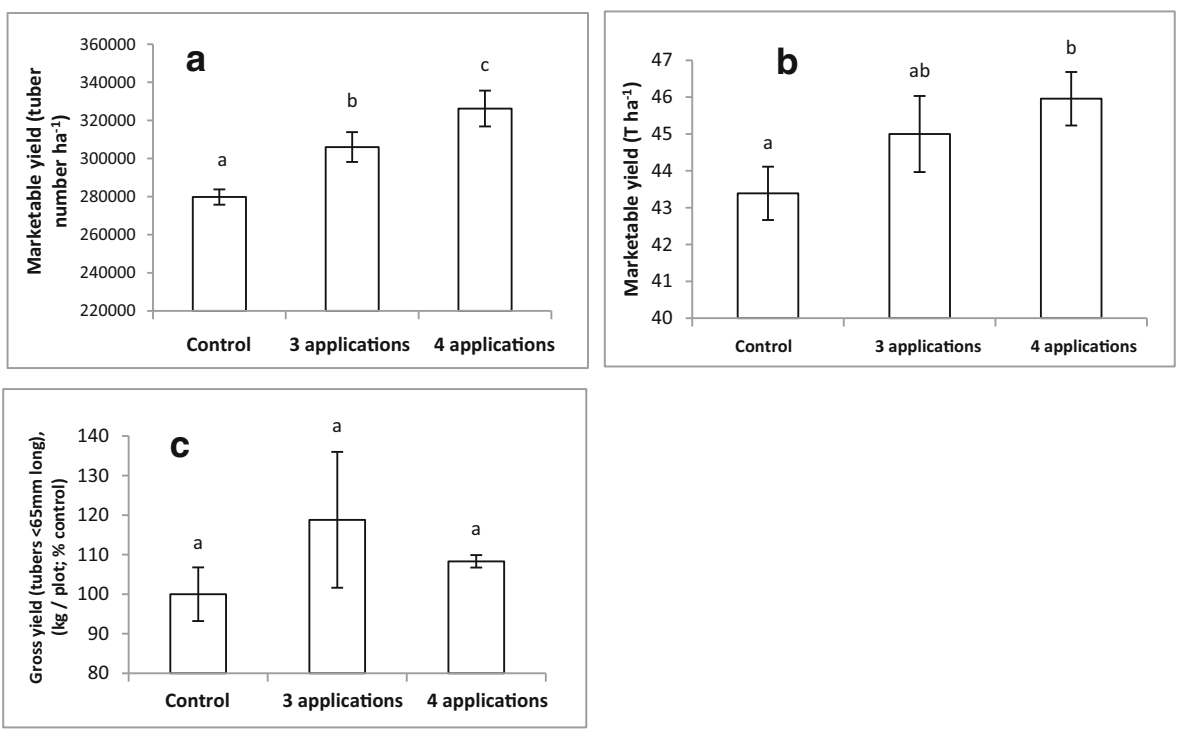

Fig. 8 a-c Effect of fertiliser N form and application rate on yields of field-grown Solanum tuberosum L. cv. Shelford (a, b) and cv. Rooster (c) at final harvest. Field trials were carried out in England (a, b) and Ireland (c) in 2016, and foliar-stabilised amine nitrogen (SAN) applications $\left(5.0 \mathrm{~L} \mathrm{ha}^{-1}\right.$ in $200 \mathrm{~L}$ water, or $0.1 \mathrm{mmol} \mathrm{m}^{-3}$ ) had either been carried out 3 or 4 times prior to measurement, or not at all (controls). Yields from 5 plots per treatment $(\mathrm{a}, \mathrm{b})$ or 4 plots per treatment $(\mathrm{c})$ are shown as means \pm standard errors: $(\mathrm{a}, \mathrm{b}) n=5$ (marketable tubers); (c) $n=4$ (gross yield by weight of tubers $<65 \mathrm{~mm}$ long, shown as $\%$ total); and significant differences between treatments are denoted by differing letters above each column $(p<0.1)$

chlorophyll content; (b) reduced shoot growth rate and shorter shoot length at tuber initiation; (c) increased relative biomass partitioning to roots prior to tuber initiation; and (d) increased shoot biomass during bulking.

The results demonstrate that the initial form of the nitrogen, rather than the amount, is the basis for the positive effects of SAN on physiology and yield, as SAN-treated plants were supplied with the same amount of total $\mathrm{N}$ by weight as IS-treated and SUtreated plants in glasshouse trials. Foliar application and soil application appear to have very similar effects on plant physiology (see Franklin et al. 2017; Wilkinson et al. 2019).

However, linking plant physiology to yield is confounded by effects of seed potato weight and the number of shoots that each seed potato produces. SAN treatment can override some of the seed potato-linked characteristics: it removes an effect of increasing shoot number to reduce root weight (Fig. 5a), and it increases root weight on a seed potato weight basis (Fig. 4b); however, seed potato effects on shoot weight alone (Fig. 4c) and on total new tissue weight (Figs. 4b, 5e) cannot be uncoupled by any $\mathrm{N}$ treatment tested here.

\section{How Does Stabilised Amine Nitrogen Increase Yield?}

The following hypotheses are discussed: (a) more total nitrogen is plant available because chemical stabilisation of urea prevents its degradation by urease, thus reducing 
volatilisation-sourced $\mathrm{N}$ loss; (b) once inside the plant, ureic $\mathrm{N}$ initially favours biomass partitioning to roots over shoots, and subsequently the large root biomass increases shoot biomass, which in turn provides more resource to tubers; (c) ureic $\mathrm{N}$ assimilation within plants is resource efficient, thereby increasing chlorophyll content and photosynthesis, for greater overall provision of energy, carbon and biomass.

\section{Increased Nitrogen Availability}

All potato plants in the glasshouse had access to the same amount of total $\mathrm{N}$ each time they were fertilised; however, those given industry-standard soluble N-P-K or nonstabilised urea may have had access to less total $\mathrm{N}$ between treatment dates (see Cantarella et al. 2018). The volatilisation and loss of ammonia $\left(\mathrm{NH}_{3}\right)$ to the atmosphere are a major cause of the often low recoveries of fertiliser $\mathrm{N}$ (about 30-70\%) detected after foliar urea application (see Witte et al. 2002). However, Witte et al. (2002) demonstrated this value to be $15 \%$ in a field-grown Desirée potato crop, by analysing the fate of foliar-applied urea $\mathrm{N}$ using a ${ }^{15} \mathrm{~N}$ radioactive tracer mass balance technique. We assume that a similar degree of $\mathrm{N}$ loss would have occurred from the canopy of conventionally treated Rooster and Shelford in the field, although it is more difficult to assess $\mathrm{N}$ loss from greenhouse-grown Casablanca. Airflow within greenhouses, even where ventilated, is less than that in the field, such that the contribution of reductions in volatilisation to the improved yields under SAN may have been small.

\section{Biomass Partitioning Between Roots and Shoots}

Chronological events during plant development that are altered by SAN are as follows: increased chlorophyll (Figs. 1 and 7), reduced shoot growth rate and length (Figs. 3, 5 and 6), increased relative root weight (Figs. 4, 5, 6), increased tuber yield at midbulking (Fig. 7) and at final harvest (Fig. 8). We propose that the first three events eventually give rise to increases in shoot-sourced resource for improved tuber growth, because increased root to shoot weight ratio at early growth stages increases aboveground tissue weight at later growth stages (Franklin et al. 2017).

Franklin et al. (2017) synthesised results from the literature for multiple species regarding the effect of $\mathrm{N}$ form on plant phenotype. Root to shoot ratio was up to three times higher as a result of resource partitioning to the root system, and nitrogen productivity up to $20 \%$ higher when plants were supplied with organic $\mathrm{N}$, compared with inorganic N. It is pertinent that the inorganic $\mathrm{N}$ form, nitrate, at sufficiency, is actively involved in the inhibition of early lateral root development (Walch-Liu et al. 2006).

Shoots and roots compete for internal assimilate, and vigorous vegetative parts can reduce root system size, and in the case of potato, tuber size, and vice versa. However, whilst SAN-induced resource partitioning to roots may be a consequence of these organs being the major site of ureic amine assimilation (see Wilkinson et al. 2019), other mechanisms will also have a role in the formation of this phenotype. Similarly, the observed SAN-induced reduction in shoot growth may be a consequence of the lack of nitrogen assimilate partitioned above ground; however, evidence shows that there will also be more direct effects on growing shoot cells. Shorter genotypes of a range of species have in common low concentrations of the shoot growth-enhancing hormone 
gibberellic acid (GA; see Gou et al. 2011). Farmers using GA inhibitors such as paclobutrazol have demonstrated increased yields of root and tuber crops because assimilate partitioning to shoots is reduced. Balamani and Poovaiah (1985) demonstrated, in potato, that paclobutrazol reduced stem elongation and shoot dry weight and increased tuber dry weight. Nagel and Lambers (2002) demonstrated that GA-deficient tomato mutants were shorter, exhibited increased nitrogen assimilation and partitioned more carbon to the roots. Gou et al. (2011) investigated effects of a gene subfamily involved in GA inactivation in poplar. Shoot- and leaf-expressed genes reduced GA concentration and specifically restrained aerial shoot growth, and root-expressed genes also reduced GA concentration whilst promoting root development, by increasing numbers of lateral root primordia, and thereby numbers of lateral roots. Whilst GArelated genes apparently control root to shoot biomass partitioning, and reductions in GA concentration are involved in increasing root to shoot ratio and potato yield (Carrera et al. 2000), reflecting the effect of SAN, to the best of our knowledge, effects of $\mathrm{N}$ form on gibberellic acid regulation are unknown. Thus, reduced shoot growth and increased root weight may not solely be linked in terms of direct competition for resource. We demonstrated that SAN mimicked the characteristics of reduced apical dominance when soil-applied to flowering plants (Wilkinson et al. 2019): increased root growth and increased shoot branching eventually led to increases in flowering. Nitrate, organic amine and ammonium have differing effects on the rate of production, transport and relative abundance of the growth hormones cytokinin and auxin within plant organs (Andrews et al. 2013; Esteban et al. 2016). Organic N tends to reduce auxin in shoots and increase its concentration in roots, whilst nitrate increases its concentration in shoots. These hormones interact to control both root and shoot physiologies, and have particular relevance to apical dominance and to lateral root and shoot production. Interestingly, the gibberellic acid hormone signalling pathway has also been shown to interact with cytokinin and auxin (Sugiura et al. 2015; Huang et al. 2017), and Sugiura et al. (2015) describe an involvement of GA-cytokinin crosstalk in biomass partitioning responses to nitrogen availability. It will be beneficial to investigate effects of SAN on auxin, cytokinin and gibberellin biology.

\section{The Relevance of Root to Shoot Ratio}

This data provides evidence that early, tuberisation-stage increases in root to shoot weight ratio may be one mechanism by which SAN eventually improves yield in potato, despite the absence of a correlation between root to shoot weight ratio and tuber yield when Casablanca was examined shortly after tuberisation (not shown). Presumably, the putative effect of increased root to shoot weight ratio to increase yield needs more time to establish. Nevertheless, we argue that a high root to shoot ratio during early plant development may be beneficial to final yield, as the larger root system provides more resource for shoots at later developmental stages; but once this effect enables shoots to thrive, as a consequence, shoot weight overtakes root weight as the driver of increased tuber yield. Figure 7 shows that Casablanca tuber weight at midbulking is positively correlated with increasing shoot weight, and that this is only significant in the case of SAN. Closer to final harvest, the dominant need is for shoots to provide tubers with resource. Nevertheless, a high root to shoot 
weight ratio may be an important early trait for yielding in genetic screening programs (e.g. Villordon et al. 2014). Villordon et al. (2014) found that increased lateral root production was related to higher yields in root and tuber crops. Yu et al. (2015) show that differences in root dry weight and the root to shoot ratio of maize at silking, in a range of geographical locations, were not derived from variations in climate, geography or stress factors, but that NUE was positively correlated with root to shoot ratio and root dry weight.

Aside from the beneficial effect of a large root system for resource provision to shoots at later growth stages, large root to shoot ratios can also have positive effects on plant health and development at early growth stages. This phenotype will be strategically important if field conditions become stressful, under nutrient or water deficiency for example, or during high winds that induce lodging: plants will already be 'armed' with the larger root systems, or the shorter shoots, whilst plants fertilised by other $\mathrm{N}$ forms require time and energy to achieve this structure only once the stress has been perceived. We have demonstrated that this phenotype is stress resilient in seedlings of a range of flowering plants (Wilkinson et al. 2019).

\section{Increased Photosynthesis}

Figures 1 and 7, and Wilkinson et al. (2019), show that relative chlorophyll content is increased by SAN, both in the field (Rooster canopy greenness) and in the glasshouse. Urea-induced increases in leaf light absorptance and photosynthesis will provide more carbon skeletons for the plant as a whole, and we have shown that this biomass is more likely to be partitioned to roots initially, and then to shoots and tubers. We propose that increases in chlorophyll content arise from resource conservation and increased internal $\mathrm{N}$ utilisation efficiency under ureic N assimilation. Shao et al. (2013) demonstrated that net photosynthetic rate, chlorophyll concentration and leaf-area index were increased significantly under controlled-release urea (CRU), compared with conventional urea-treated maize plants at grain filling, and produced a higher yield, although this may simply relate to the higher availability of nitrogen per se with reduced degradation. However, Esteban et al. (2016) demonstrated experimentally that the biophysical parameters of the photosynthetic apparatus of urea-grown Medicago trunculata plants displayed a dosedependent improvement in energy conservation, which was higher than that observed in nitrate- and ammonium-treated plants. Thus, ureic nutrition could increase photosynthesis more directly, in addition to increasing light absorptance as a consequence of resource-conserving $\mathrm{N}$ assimilation, when compared with inorganic nitrogen nutrition. Stabilised ureic amine could increase the efficiency with which intercepted radiation is used to produce dry matter.

\section{Conclusions}

Urea amine nitrogen, when stabilised, allows plants to achieve an archetype (optimal phenotype) in terms of physiology and form, for making best use of resource and transposing this into a maximal reproductive or starch storage capacity. The archetype, 
at least until tuber initiation, has an increased root to shoot weight ratio (Figs. 4, 5, 6); a higher relative chlorophyll content (Figs. 1, 7; Wilkinson et al. 2019); and less apical dominance through slower shoot extension rates and a relatively larger root system (Figs. 3, 4, 5; also characterised by lateral shoot growth, Wilkinson et al. 2019). This structural form provides resilience to stresses such as drought, nutrient deficiency, lodging and salinity (see Wilkinson et al. 2019; Yu et al. 2015). At later growth stages, because this archetype maximises provision of resource to shoots, root to shoot weight ratios become less relevant to tuber yield. Rather, the shoots and their high photosynthetic capacity become dominant for providing both nitrogen at early bulking and sucrose at mid-late bulking. Figure 7 shows that mid-bulking shoot weight and tuber weight are positively correlated only in SAN-treated plants. We propose that this archetype can also be achieved in the field by using stabilised amine nitrogen, resulting in increased yielding (Fig. 8). A simple alteration in nutritional form (and its maintenance through chemical stabilisation) can provide system-wide changes in plant physiology and phenotype which increase plant stress resilience, NUE, internal nitrogen utilisation efficiency, photosynthetic performance, partial factor productivity and yield.

Acknowledgements The authors would like to thank Stephen Houghton (Levity Crop Science Ltd., Preston, UK) for assistance with fertiliser chemical formulations, and Myerscough College \& University Centre (Preston, UK) for provision of glasshouse space.

\section{Compliance with Ethical Standards}

Conflict of Interest In accordance with our ethical obligation as researchers, we are reporting that we are employees of a company that may be affected by the research reported in the enclosed paper. Mention of commercial products in this publication is solely for the purpose of providing specific information and does not imply recommendation or endorsement. Other stabilised $\mathrm{N}$ products can be used to carry out similar research; and/or complimentary provision of SAN can be arranged.

Open Access This article is distributed under the terms of the Creative Commons Attribution 4.0 International License (http://creativecommons.org/licenses/by/4.0/), which permits unrestricted use, distribution, and reproduction in any medium, provided you give appropriate credit to the original author(s) and the source, provide a link to the Creative Commons license, and indicate if changes were made.

\section{References}

del Amor FM, Cuadra-Crespo P, Varó P, Gómez MC (2009) Influence of foliar urea on the antioxidant response and fruit color of sweet pepper under limited N supply. J Sci Food Agric 89:504-510. https://doi. org/10.1002/jsfa.3485

Andrews M, Raven J, Lea P (2013) Do plants need nitrate? The mechanisms by which nitrogen form affects plants. Ann Appl Biol 163:174-199. https://doi.org/10.1111/aab.12045

Arkoun M, Sarda X, Jannin L, Laîné P, Etienne P, Garcia-Mina J-M, Ourry A (2012) Hydroponics versus field lysimeter studies of urea, ammonium and nitrate uptake by oilseed rape (Brassica napus L.). J Exp Bot 63:5245-5258. https://doi.org/10.1093/jxb/ers183

Balamani V, Poovaiah BW (1985) Retardation of shoot growth and promotion of tuber growth of potato plants by paclobutrazol. Am Potato J 62:363-369. https://doi.org/10.1007/BF02855607

Barthelemy H, Stark S, Michelsen A, Olofsson J (2018) Urine is an important nitrogen source for plants irrespective of vegetation composition in an Arctic tundra: insights from a ${ }^{15} \mathrm{~N}$-enriched urea tracer experiment. J Ecol 106:367-378. https://doi.org/10.1111/1365-2745.12820 
Bhogal A, Dampney P, Goulding K (2003) Evaluation of urea-based nitrogen fertilisers. Report for Defra (UK) projects NT2601 and NT2602. http://www.envirobase.info/PDF/RES31087_final_report.pdf

Cambui CA, Svennerstam H, Gruffman L, Nordin A, Ganeteg U, Näsholm T (2011) Patterns of plant biomass partitioning depend on nitrogen source. PLoS One 6. https://doi.org/10.1371/journal.pone.0019211

Cantarella H, Otto R, Soares RJ, Gomes de Brito Silva A (2018) Agronomic efficiency of NBPT as a urease inhibitor: a review. J Adv Res 13:19-27. https://doi.org/10.1016/j.jare.2018.05.008

Carrera E, Bou J, García-Martínez JL, Prat S (2000) Changes in GA 20-oxidase gene expression strongly affect stem length, tuber induction and tuber yield of potato plants. Plant J 22:247-256. https://doi. org/10.1046/j.1365-313x.2000.00736.x

Chalk PM, Craswell ET, Polidoro JC, Chen D (2015) Fate and efficiency of ${ }^{15} \mathrm{~N}$-labelled slow- and controlledrelease fertilizers. Nutr Cycl Agroecosyst 102:167-178. https://doi.org/10.1007/s10705-015-9697-2

Dawar K, Zaman M, Rowarth JS, Blennerhassett JD, Turnbull MH (2011) Urea hydrolysis and lateral and vertical movement in the soil: effects of urease inhibitor and irrigation. Biol Fertil Soils 47:139-146. https://doi.org/10.1007/s00374-010-0515-3

Esteban R, Royo B, Urarte E, Zamarre AM, Garcia-Mina JM, Moran JF (2016) Both free indole-3-acetic acid and photosynthetic performance are important players in the response of Medicago truncatula to urea and ammonium nutrition under axenic conditions. Front Plant Sci 7 https://www. frontiersin. org/article/10.3389/fpls.2016.00140

Franklin O, Cambui CA, Gruffman L, Palmroth S, Oren R, Näsholm T (2017) The carbon bonus of organic nitrogen enhances nitrogen use efficiency of plants. Plant Cell Environ 40:25-35. https://doi.org/10.1111/pce.12772

Gooding MJ, Davies WP (1992) Foliar urea fertilization of cereals: a review. Fertilizer Res 32:209-222. https://doi.org/10.1007/BF01048783

Gou J, Ma C, Kadmiel M, Gai Y, Strauss S, Jiang X, Busov V (2011) Tissue-specific expression of Populus $\mathrm{C}_{19}$ GA 2-oxidases differentially regulate above- and below-ground biomass growth through control of bioactive GA concentrations. New Phytol 192:626-639. https://doi.org/10.1111/j.14698137.2011.03837.x

Hannapel DJ, Sharma P, Lin T, Banerjee AK (2017) The multiple signals that control tuber formation. Plant Physiol 174:845-856. https://doi.org/10.1104/pp.17.00272

Heffer P, Prud'hommer M (2014) Fertilizer outlook 2014-2018. International Fertilizer Industry Association (IFA), 26-28 May 2014, Sydney

Hoult EH, McGarity JW (1986) The measurement and distribution of urease activity in a pasture system. Plant Soil 93:359-366. https://doi.org/10.1007/BF02374286

Huang W, Peng S, Xian Z, Lin D, Hu G, Yang L, Ren M, Li Z (2017) Overexpression of a tomato miR171 target gene SlGRAS24 impacts multiple agronomical traits via regulating gibberellin and auxin homeostasis. Plant Biotechnol J 15:472-488. https://doi.org/10.1111/pbi.12646

Hutchinson C, Simonne E, Solano P, Meldrum J, Livingston-Way P (2002) Testing of controlled release fertilizer programs for seep irrigated Irish potato production. J Plant Nutr 26:1709-1723. https://doi. org/10.1081/PLN-120023277

Hyatt CR, Venterea RT, Rosen CJ, McNearney M, Wilson ML, Dolan MS (2009) Polymer-coated urea maintains potato yields and reduces nitrous oxide emissions in a Minnesota loamy sand. Soil Sci Soc Am J 74:419-428. https://doi.org/10.2136/sssaj2009.0126

Klein I, Weinbaum S (1985) Foliar application of urea to almond and olive: leaf retention and kinetics of uptake. J Plant Nutr 8:117-129. https://doi.org/10.1080/01904168509363329

Krogmeier MJ, McCarty GW, Bremner JM (1989) Potential phytotoxicity associated with the use of soil urease inhibitors. Proc Natl Acad Sci U S A 86:1110-1112. https://doi.org/10.1073/pnas.86.4.1110

Liu X, Zhang Y, Han W, Tang A, Shen J, Cui Z, Zhang F (2013) Enhanced nitrogen deposition over China. Nature 494:459-462. https://doi.org/10.1038/nature11917

Marks DJ, Wilkinson S, Weston AK (2018) Influence of foliar stabilised nitrogen on potato tuber yield. Proc Crop Production in Northern Britain, 225-230 (8, 20183245174); pub. by 'The Association for Crop Protection in Northern Britain, Dundee, UK'. The Dundee Conference. Crop Production in Northern Britain 2018, Dundee, UK,

Nagel OW, Lambers H (2002) Changes in the acquisition and partitioning of carbon and nitrogen in the gibberellin-deficient mutants $A 70$ and W335 of tomato (Solanum lycopersicum L.). Plant Cell Environ 25: 883-891. https://doi.org/10.1046/j.1365-3040.2002.00871.x

Neff JC, Chapin FS, Vitousek PM (2003) Breaks in the cycle: dissolved organic nitrogen in terrestrial ecosystems. Front Ecol Environ 1:205-211. https://doi.org/10.1890/1540-9295(2003)001[0205 :BITCDO]2.0.CO;2 
Paungfoo-Lonhienne C, Lonhienne TGA, Rentsch D, Robinson N, Christie M, Webb RI, Schmidt S (2008) Plants can use protein as a nitrogen source without assistance from other organisms. Proc Natl Acad Sci U S A 105:4524-4529. https://doi.org/10.1073/pnas.0712078105

Prasad R, Singh G, Shivay YS, Pathak H (2016) Need for determining eco-friendly optimum fertilizer nitrogen level for better environment and for alleviating hunger and malnutrition. Indian J Agron 61:1

Schimel JP, Bennett J (2004) Nitrogen mineralization: challenges of a changing paradigm. Ecol 85:591-602. https://doi.org/10.1890/03-8002

Shao G, Li Z, Ning T, Zheng Y (2013) Responses of photosynthesis, chlorophyll fluorescence, and grain yield of maize to controlled-release urea and irrigation after anthesis. Z Pflanzenernähr Bodenk 176:595-602. https://doi.org/10.1002/jpln.201100185

Soares JR, Cantarella H, Leite de Campos Menegale M (2012) Ammonia volatilization losses from surfaceapplied urea with urease and nitrification inhibitors. Soil Biol Biochem 52:82-89. https://doi.org/10.1016 j.soilbio.2012.04.019

Sugiura D, Sawakami K, Kojima M, Sakakibara H, Terashima I, Tateno M (2015) Roles of gibberellins and cytokinins in regulation of morphological and physiological traits in Polygonum cuspidatum responding to light and nitrogen availabilities. Funct Plant Biol 42:397-409. https://doi.org/10.1071/FP14212

Sunil B, Talla SK, Aswani V, Raghavendra AS (2013) Optimization of photosynthesis by multiple metabolic pathways involving inter-organelle interactions: resource sharing and ROS maintenance as the bases. Photosynth Res 117:61-71. https://doi.org/10.1007/s11120-013-9889-Z

Tiana X, Lia C, Zhang M, Li T, Lu Y, Liu L (2018) Controlled release urea improved crop yields and mitigated nitrate leaching under cotton-garlic intercropping system in a 4-year field trial. Soil Tillage Res 175:158167. https://doi.org/10.1016/j.still.2017.08.015

Trenkel ME (2010) Slow-and controlled-release and stabilized fertilizers: an option for enhancing nutrient use efficiency in agriculture. International Fertilizer Industry Association, (IFA), Paris

Villordon AQ, Ginzberg I, Firon N (2014) Root architecture and root and tuber crop productivity. Trends Plant Sci 19:419-425. https://doi.org/10.1016/j.tplants.2014.02.002

Walch-Liu P, Liu L-H, Remans T, Tester M, Forde BG (2006) Evidence that L-glutamate can act as an exogenous signal to modulate root growth and branching in Arabidopsis thaliana. Plant Cell Physiol 47: 1045-1057. https://doi.org/10.1093/pcp/pcj075

Wang S, Zhao X, Xing G, Yang Y, Zhang M, Chen H (2015) Improving grain yield and reducing N loss using polymer-coated urea in Southeast China. Agron Sustain Dev 35:1103-1115. https://oi.org/10.1007 /s13593-015-0300-7

Watson CJ, Miller H (1996) Short-term effects of urea amended with the urease inhibitor N-(n-butyl) thiophosphoric triamide on perennial ryegrass. Plant Soil 184:33-45. https://doi.org/10.1007/BF00029272

Wilkinson S, Weston AK, Marks DM (2019) Stabilising urea nitrogen enhances flowering, nitrogen use efficiency, and growth habit for stress tolerance in ornamental plants. J Hort Postharv Res 2:13-30. https://doi.org/10.22077/jhpr.2018.1995.1036

Witte C-P (2011) Urea metabolism in plants. Plant Sci 180:431-438. https://doi.org/10.1016/j. plantsci.2010.11.010

Witte C-P, Tiller SA, Taylor MA, Davies HV (2002) Leaf urea metabolism in potato. Urease activity profile and patterns of recovery and distribution of $\left({ }^{15}\right) \mathrm{N}$ after foliar urea application in wild-type and ureaseantisense transgenics. Plant Physiol 128:1129-1136. https://doi.org/10.1104/pp.010506

Wojcik P (2004) Uptake of mineral nutrients from foliar fertilization. J Fruit Orn Plant Res Spec 12:201-218

Yu P, Li X, White PJ, Li C (2015) A large and deep root system underlies high nitrogen-use efficiency in maize production. PLoS One 10:5. https://doi.org/10.1371/journal.pone.0126293

Zanin L, Venuti S, Tomasi N, Zamboni A, De Brito Francisco RM, Varanini Z, Pinton R (2016) Short-term treatment with the urease inhibitor n-(n-butyl) thiophosphoric triamide (NBPT) alters urea assimilation and modulates transcriptional profiles of genes involved in primary and secondary metabolism in maize seedlings. Front Plant Sci 7:845 https://www.frontiersin.org/article/10.3389/fpls.2016.00845

Zerihun A, McKenzie BA, Morton JD (1998) Photosynthate costs associated with the utilization of different nitrogenforms: influence on the carbon balance of plants and shoot-root biomass partitioning. New Phytol 138:1-11 https://www.cambridge.org/core/journals/newphytologist/article//F933700C4B4FC5B6D1CC3B46BFB84047

Zvomuya F, Rosen CJ, Russelle MP, Gupta SC (2003) Nitrate leaching and nitrogen recovery following application of polyolefin-coated urea to potato. J Environ Qual 32:480-489 https:/www.ncbi.nlm.nih. gov/pubmed/12708671?dopt=Abstract

Publisher's Note Springer Nature remains neutral with regard to jurisdictional claims in published maps and institutional affiliations. 


\section{Affiliations}

Sally Wilkinson ${ }^{1} \cdot$ Anna Kate Weston ${ }^{1} \cdot$ David James Marks ${ }^{1}$

$\triangle$ Sally Wilkinson

sally@levitycropscience.com

1 Levity Crop Science Ltd., The Rural Business Centre, Myerscough College, Preston PR3 0RY, UK 